\title{
TO BE OR NOT TO BE... A CHRISTIAN: SOME NEW PERSPECTIVES ON UNDERSTANDING THE CHRISTIANISATION OF ESTONIA
}

\author{
Tõnno Jonuks, Tuuli Kurisoo
}

\begin{abstract}
The Christianisation of Estonia has been a subject of extensive research already for a couple of centuries. Archaeologists generally agree that some elements of Christian religion were present in Estonia already prior to official Christianisation at the beginning of the 13th century. Still, speculations about what those elements were and what they meant have been avoided. We suggest that the materiality of Christianity is wider than traditional cross pendants, and other objects carrying Christian symbols should be considered as well. As a conclusion, we outline some Christian elements that were probably used by local people before the official baptism; to describe these people, a new concept - prehistoric Christians - has been taken into use.
\end{abstract}

Keywords: Christianisation, cross, pendants, symbolism, baptism

\section{INTRODUCTION}

Christianisation can be regarded as one of the most important research issues in the studies of the history of religions in Estonia. It became an actively debated issue in Estonian religiosity already during the 18th-century Enlightenment, when Baltic-German scholars developed the first general approaches to Estonian and Livonian history (e.g. Merkel 1798; Hupel 1774). Since then it has remained the fundamental issue in a majority of studies concerning the religions of ancient Estonia (e.g. Selirand 1961, 1974; Kala 1998, 2006; Valk 2003; Mägi 2002, 2004 and references therein). Christianisation is a crucial issue not only in Estonia, but could be regarded as one of the main topics also in the whole of northern Europe. It certainly has several reasons in addition to religious change, and for a researcher one of the most important of them is differences in sources. It is common that writing skills (at least in today's meaning) spread together with Christianity, which also brought along literary sources more informative than the previous limited inscriptions or archaeological remains.

But Christianisation also meant a new administrative system, in many senses new nobility and new, urban culture. Such a difference was especially 
dramatic in Estonia but could also be observed all over northern Europe. In addition, Christianity carried a new kind of identity, in which the earlier, originbased cognition was replaced by a new, world-based religion. In conclusion, all of this indicates that Christianisation led us to a new period of history, which also justifies such a great interest in the origin of the process.

But the issue of identity is also important in studying the Estonian nationality. The first researchers, the Baltic-German enlighteners in the late 18th and early 19th centuries, created an approach of a cultural gulf before and after Christianisation, pointing at free and pagan Estonians before the violent Crusade (e.g. Merkel 1798: 235). As this is also the core of Estonian Grand Narrative, Christianisation, often seen as hostile and alien, has become a milestone in studying the Estonian identity.

In these approaches two different views on the process of Christianisation can be seen - sudden and gradual. The latter is predominantly accepted by the academic audience and Christian influences are also stressed in Late Iron Age religion. The former approach - the sudden conversion - is often used by the authors of popular and more ideological studies. Similarly to enlighteners, the cultural gulf is emphasised as having been created by Christianisation as a chronologically limited event (early 13th century). According to this view, after the conquest the pagan prehistoric religion changed into conservative folk-religion under Christian rule, preserving many features from the old times. Being rather an ideological approach, it will be excluded from here further on and, instead, we will focus on a more academic tradition and try to dwell more on what those "Christian influences" might have meant in the 12th-13thcentury Estonia.

Religion has never been a favoured topic of discussion in Estonia, both for historical and political reasons (see Jonuks 2009: 32ff.), and it becomes manifest when Christianity is discussed. Too often the personal scholarly background plays a crucial role, and also influences interpretations. One and the same phenomenon has been interpreted considerably differently, or perhaps too much stress has been laid on a single feature. Thus the opposition to inhumationcremation burials, orientation of the body, presence or absence of grave goods, etc., has been used for justifying or opposing Christianity in Late Iron Age society. The main problem in many of those studies, at least according to current authors, is the simplified approach to the concepts of 'Pagan' and 'Christian', which allows for such loose interpretations about the archaeological source material. 


\section{A SHORT HISTORY OF THE IDEA}

When following the general approach to the studies of Christianisation, it becomes evident that scholars have mostly focused on either the conquest or the church history and institution. Without any doubt this is the safest approach as most of the available sources refer to these issues. At the same time the actual religiosity of the missionised folk has largely been ignored, the main reason for it being sources - all that has been written is either about official Christianity or comes from those sources, leaving little ground to speculate what local people really thought or felt. When addressing the religiosity of local people, the statement that pagan topoi of Christian clerics are used in chronicles is most often followed (Tamm \& Jonuks forthcoming). And indeed, none of the 12th-13th-century chronicles and clerics were anthropologists and what local people believed either prior to or after Christianisation was never an issue for them. It was more important to make the crusaders' achievements immortal as it is presented in the introduction of crusade period chronicles (Selart 2008: 199). Another, religiously even more crucial goal was to express otherness, the pagan side of those strange savages, therefore legitimising also Christianisation as such (Kaljundi 2008; Tamm forthcoming, and references therein).

One can point to several examples in the approach, some of the most colourful of which are descriptions of pagan burial customs. According to the words of chronicles from the 12th and 13th centuries only cremation was used by locals. Even though cremation has been used in Christian contexts throughout history as an accepted burial custom in extreme situations, it had become a characteristic feature of pagan societies by the time of Livonian mission at the end of the 12 th century. All chronicles from that period mention cremation only in connection with locals, stressing the pagan and alien religion and culture. As it is known from archaeology, inhumation cemeteries were widespread all over Livonia and Estonia at that time and it is highly unlikely that priest Henry of Livonia, the best known chronicler of the period, did not know about it. Thus, the prevailing description of cremations should not be regarded as a description of local culture, but rather as a pagan topos that was interesting and important to Christian chronicles. Subsequently, the study of the history of Christianisation in Estonia has recently focused especially on crusades and on how foreign crusaders saw the last pagan part of Europe (Kaljundi 2008; Tamm 2009). Thus, the research focus has slightly shifted among historians and it is the viewpoint of foreigners and the wider European perspective that is being taken into account now.

Still, the issue of Christianisation has preserved its prominence in archaeological studies, and has resulted in a reinterpretation of many archaeological 
finds. Scholars have been remarkably unanimous when stating that people who lived in what today is Estonia had some Christian influences that had reached them already before official Christianisation at the beginning of the 13th century (Selirand 1961, 1974: 186; Loorits 1962: 218; Pauts 1997; Valk 2001; Mägi 2002, 2004; Leimus 2009). Unfortunately, suggestions of what these influences mean have been considered too speculative and this issue has been avoided. But before we start to speculate about the religiosity of Final Iron Age Estonia, we have two crucial issues to resolve: Which archaeological material can be related to Christianity? What are Christianity and Paganism altogether?

\section{ARCHAEOLOGICAL APPROACH}

As compared to literary sources, archaeology offers richer and more varied material; however, in the latter interpretations are in many ways more speculative than those in written sources. Estonian archaeological material in general is very poor in symbolism and the most widespread signs are abstract marks to which different meanings could be ascribed (see Jonuks 2009). Considering the wide use of different ornaments, it rather seems more appropriate to suggest that these might have been simply aesthetic marks without any symbolic meaning. Even though some ornament styles, like the triangular 'wolf-teeth' signs on brooches and bracelets, have been interpreted as 'pagan' (Pauts 1997) or magic symbols (Tamla \& Kiudsoo 2009: 48), they rather seem to appear in all possible connections with other symbols and thus cannot be interpreted as carrying some specific 'pagan identity'. The shortage of signs is especially eyecatching considering the rich variety of Christianity-related symbolism in the 12 th and 13 th centuries.

We are not going to present the spread of cross symbolism in Estonia in detail as it can, to some extent, be studied on the basis of previously published researches (Selirand 1974; Leimus 2009; Kurisoo 2012). In short, it can be stated that cross pendants first appear at the end of the 11th century and by the late 12 th and early 13 th centuries the cross is the most popular and widely used symbol in Estonia. In addition to cross-shaped pendants, similar kind of symbols decorate round silver pendants, but the cross also appears as an ornament motif on bracelets, sword sheaths, penannular brooches, etc. The earliest forms of pendants appear mostly in wealth deposits dating from the end of the 11 th century onwards, while by the end of the 12 th century cross pendants also occur among burials, mostly in those of females or children (Kurisoo 2012), and thus the situation is similar to that in north-western Russia (Musin 2012: 508). This is quite interesting as Estonian data have mostly been gathered from the 


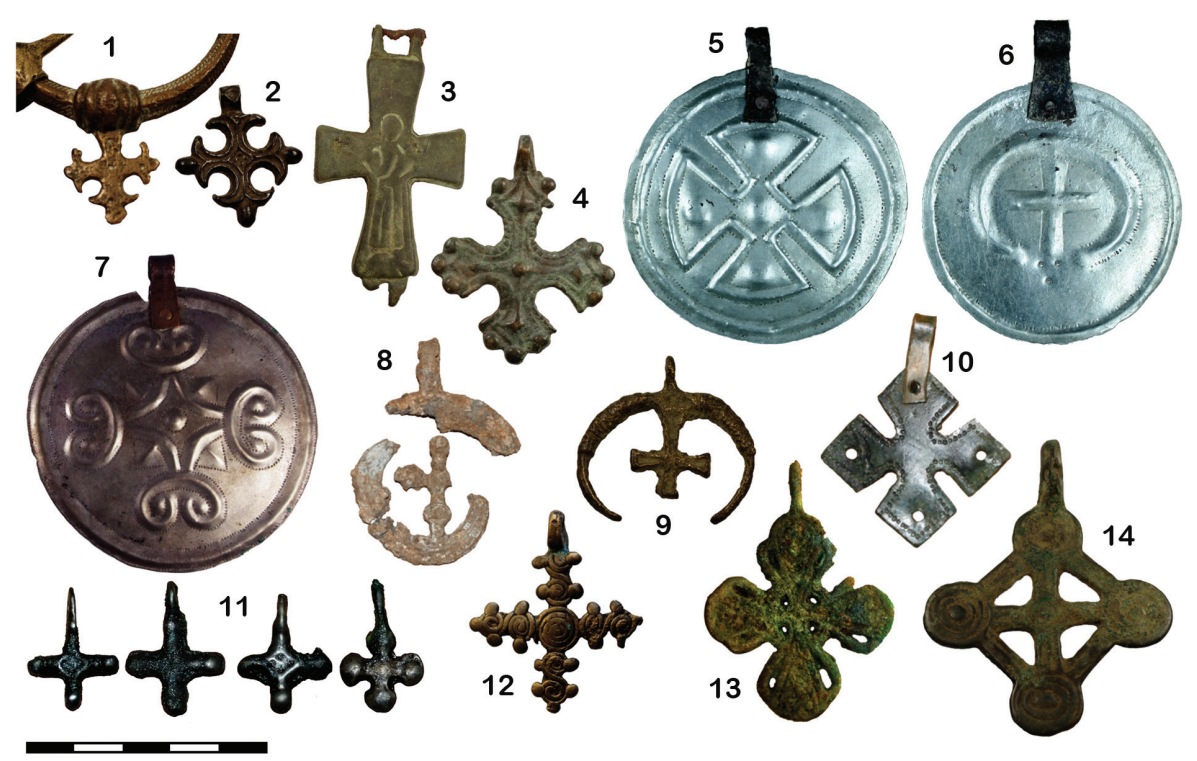

Figure 1. A selection of 12th-13th-century jewellery with cross symbolism (1 - TLM 16373; 2 - TLM A93:134; 3 - AI 3884: 2956; 4 - AI 3579: 4; 5 - TÜ 1777: 1257; 6 - TÜ 1777: 1256; 7 - AM 290; 8 AM 1036: 156; 9 - AI 2670: 7; 10 - AI 4116: 138B; 11 - AM 1036: 124; 12 - AI 4133; 13 - TÜ 1777: VI; 14 - AI 2513: 19). Photos by Tõnno Jonuks and Tuuli Kurisoo 2013.

northern and western part of the country. At the same time, just across the Gulf of Finland, cross pendants in southern Finland are more characteristic of male burials (Purhonen 1998: 150). But either way, in all those countries, and also more widely in northern Europe, cross symbolism is characteristic of wealthy burials (Staecker 1999; Gräslund 2000).

Round silver pendants with cross signs also occur in burials dating from the end of the 12th and largely from the beginning of the 13th century, still being more numerous in wealth deposits. Among other cross pendants, a more unique item is known from Viltina cemetery, Saaremaa, where an encolpion was found from a cremation burial stone grave (Jonuks 2009: 296) (Fig. 1: 3). This find clearly represents an import that can also be associated with exotic souvenirs, magical objects, etc., and despite its originally Christian meaning this might have changed while the object was taken out of its original context (cf. Schülke 1999). However, taking into account the fact that at least four cross pendants were found in the same grave, it is likely that the original meaning of the encolpion, which was associated with Christianity, was preserved. 
Another unique find, a cross pendant from a hoard found in Tartu, should be mentioned here (see Tvauri 2001: 74). It is the only example from Estonia of a pendant depicting crucified Christ, while the same style is more widespread both in Western Europe (see Staecker 1999) and northern and western Russia (Musin 2012).

Conventionally, cross pendants have been divided into two types, based on their possible origin - the 'Scandinavian' and the 'Russian'. Russia has traditionally been considered a source of Christian influences for Estonia (e.g. Selirand 1961). Jüri Selirand (1974) was the first in Estonia to raise the issue of locally made cross pendants, which created the basis for considerably different interpretations (see below). As some recent studies have shown (Kurisoo 2012), at least a quarter of cross pendants from inhumation burials are of local origin and, as such, carry the local meaning instead of an imported tradition. The same is also valid for round silver pendants that represent the 'FinnishEstonian type', have been locally produced and thus, carry the meaning that local people have ascribed to them. Ivar Leimus (2009) has suggested multiple influences for the cross to become a central motif of the aforementioned pendants, and it seems likely that in many cases it is actually the cross pendant that is represented on a silver disc (Fig. 2).
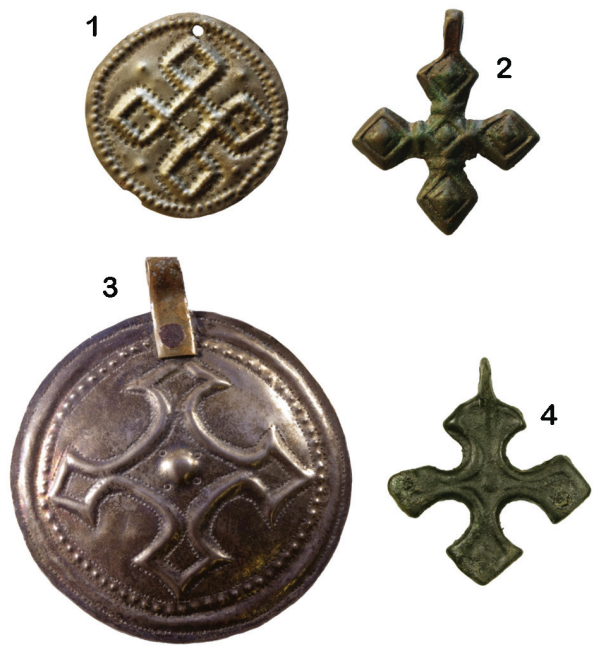

Figure 2. Cross pendants and a round silver pendant from Savastvere and Kumna hoards (1 - AI 3355: 42; 2 - AI 3355: 38; 3 - AM 434; 4 -AM 580: 6161). Note the similarities between cross pendants and the cross on the round pendant. Photo by Tuuli Kurisoo 2013. 
Thus, we could suggest that cross pendants and round pendants with a cross sign actually carry the same meaning. While checking the position of such pendants in burials, it is apparent that round pendants were really worn in the same way as cross pendants. But, in addition, cross pendants have also been represented in the extensions of some penannular brooches, suggesting semantic similarities as well (cf. Ó Floinn 2012: 18).

Theoretically, it is much easier to ascribe magical meanings to foreign objects as they are moved away from their original context. However, cross symbolism created, used and reinterpreted locally indicates that the symbol that (it must be stressed here again) was the most widespread in the Late Iron Age, had a meaning also in officially pagan Estonia and the purport most likely derived from the general Christian framework. The same argument has also been used in the studies of early Christianity elsewhere, for instance, in Bulgaria (Pluskowski \& Patrick 2003: 48 and references therein). But the numerous imported cross pendants of more widespread types most likely carry the same meaning and, considering the wider sense of symbolism during that period, cannot be interpreted as magical amulets.

As a brief conclusion, it can be stated that most probably the cross in the 12th-13th-century Estonia had a rather uniform background and it was not important from the semantic point of view in which form it was represented. On the contrary: crosses worn as pendants, as symbols on round silver pendants or as extensions of penannular brooches all seem to carry the same wider idea (see also Leimus 2009). But what could it be about?

\section{Traditional interpretations of cross symbolism}

In the interpretations of cross symbolism two main approaches are used, both of which are connected with the cross as a sign. The first of them can be exemplified as 'magic'. The wider background to this approach is that the cross is an ancient and pagan symbol and, as such, should be interpreted as a universal pagan and magical sign and should not be exclusively connected to Christianity. Without any doubt the cross as a rather simple and universal symbol appears in various contexts, starting from the Palaeolithic cave paintings, and is represented universally in many cultures throughout the entire prehistory and history. It is also obvious that the cross occurs in many 'pagan' contexts, for instance, together with teeth-pendants (Laul \& Valk 2007: 123 and references therein) or numerous cross pendants combined in the same necklace (Kallis 2010: 160f.) (Fig. 3). 


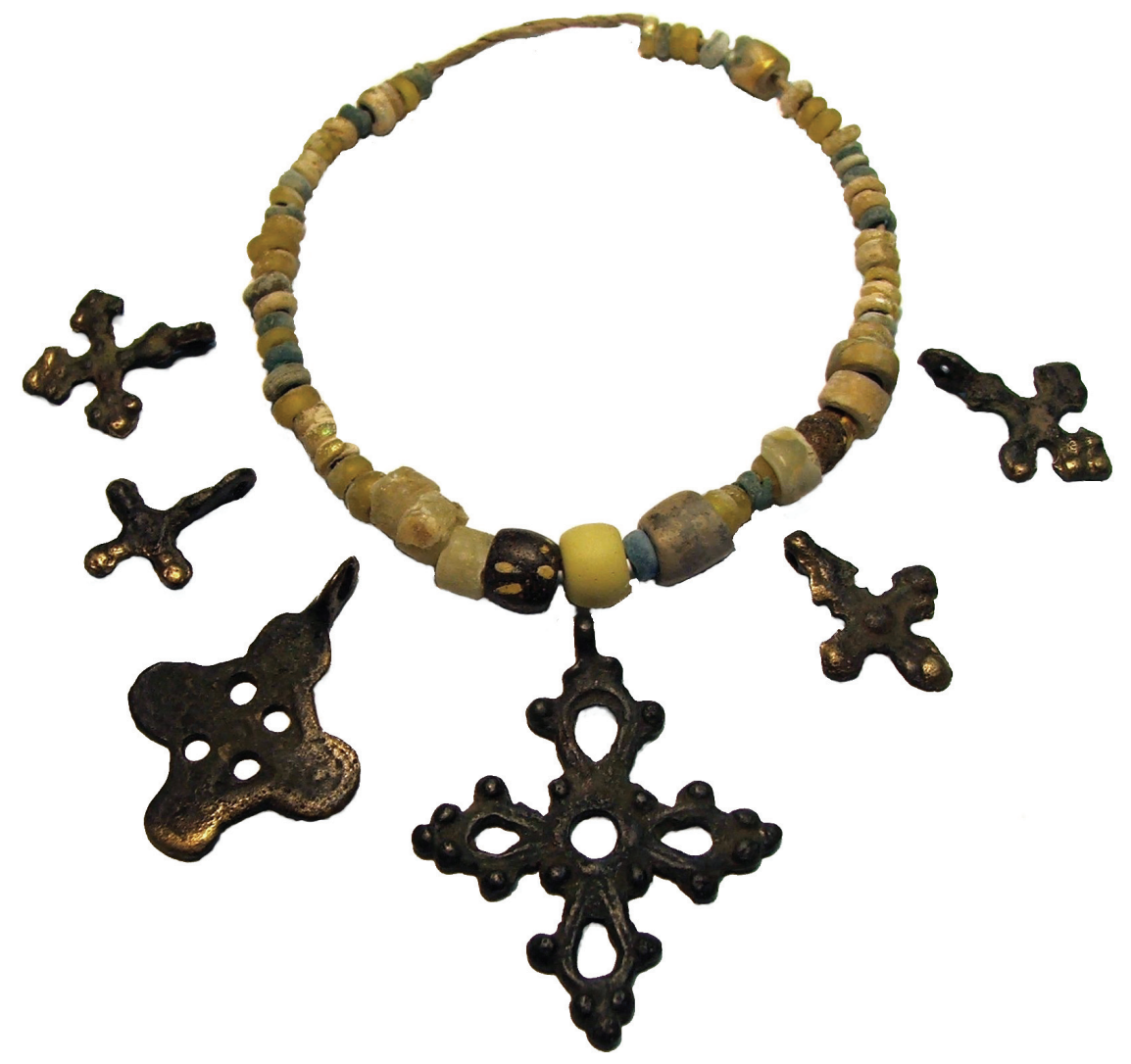

Figure 3. A necklace from Kaberla burial CLXXXIII. Note the multiple cross pendants. The third from the left is made of an ornamental pin. Photo by Irita Kallis (2010: 165).

None of those cases really resemble the way that the cross should have been worn in Christianity, hence magical interpretations seem to be reasonable. But we should also recognise that the meaning of a sign is determined by its temporal and cultural context. Bearing this in mind, we can see that cross symbolism actually appears in Estonia only from the late 11th century onwards and not before $^{1}$; it spreads more widely in the 12 th century and is most widespread in the early 13 th century. Thus, the spread of cross signs in Estonia corresponds well with the Christianisation of the neighbouring countries. Considering the latter, it is more likely that the cross in Final Iron Age Estonia had its meaning derived from Christianity and not from a sort of universal paganism. The actual 
use of the cross symbol is another issue and without doubt the cross might have been in use as a magical sign, as a protective amulet, etc. But the supernatural power of the symbol derives from Christian religion, hence it should still be considered as a Christian symbol even though its actual use was different from that in traditional Christianity (see also Samdal 2000: 88f.).

According to another approach, which is the most frequently represented one in academic studies and is also crucial to this study, the cross represents Christian symbolism and reflects Christian influences in Estonian Final Iron Age religion (e.g. Moora 1927: 5; Selirand 1961; Mägi 2002; Valk 2003). Even though it is widely accepted, it differs in how we understand 'Christian influences' and what labels of identity we are allowed to ascribe to those people. Depending on this, the understanding of 'Christian influences' can be dramatically different, starting from indirect influences and reaching up to baptised persons. But according to the dominating tradition the abstract notion influences' is no more precisely determined.

\section{Other Christianity-related archaeological materials}

Traditionally it is the cross that has been regarded as the main source material for Christian religion. However, the cross is not the only symbol - the symbolism of Christianity can be much more varied. Pentagram-signs are quite rarely found on round silver pendants, which should probably be interpreted as Christian symbolism and, similarly, the four-legged swastika on some round silver pendants can be considered as the interpretation of the cross. Some unique examples include round pendants made of bronze, which carry a depiction of Christ and were found in Savastvere hoard, originating from the second half of the 12th century (Tamla \& Kiudsoo 2009: 42) and in Kobratu stone grave. The style and position of Christ on both of these indicate that the East is the source of the aforementioned pendants (Fig. 4: 1, 2).

Among other rarer examples are the separated heads of cross-headed pins, which were also worn as cross-pendants (Tamla 1993; Kurisoo 2012). Deliberately smoothed surfaces of the fracture indicate that heads of those pins were remanufactured by intension (Fig. 4: 3).

But in addition to symbols, there have been a few more exotic cases, such as pieces of painted ceramic eggs, which were found in Tartu (Tvauri 2001: 162) (Fig. 4: 4, 5) and associated with the Easter egg tradition symbolising the rebirth of one's soul. Such items were especially popular in Russia, and Kiev is considered to have been the major production base for them. Closely connected to the latter, a red ochre-painted bird egg dating from the early 13 th century, 


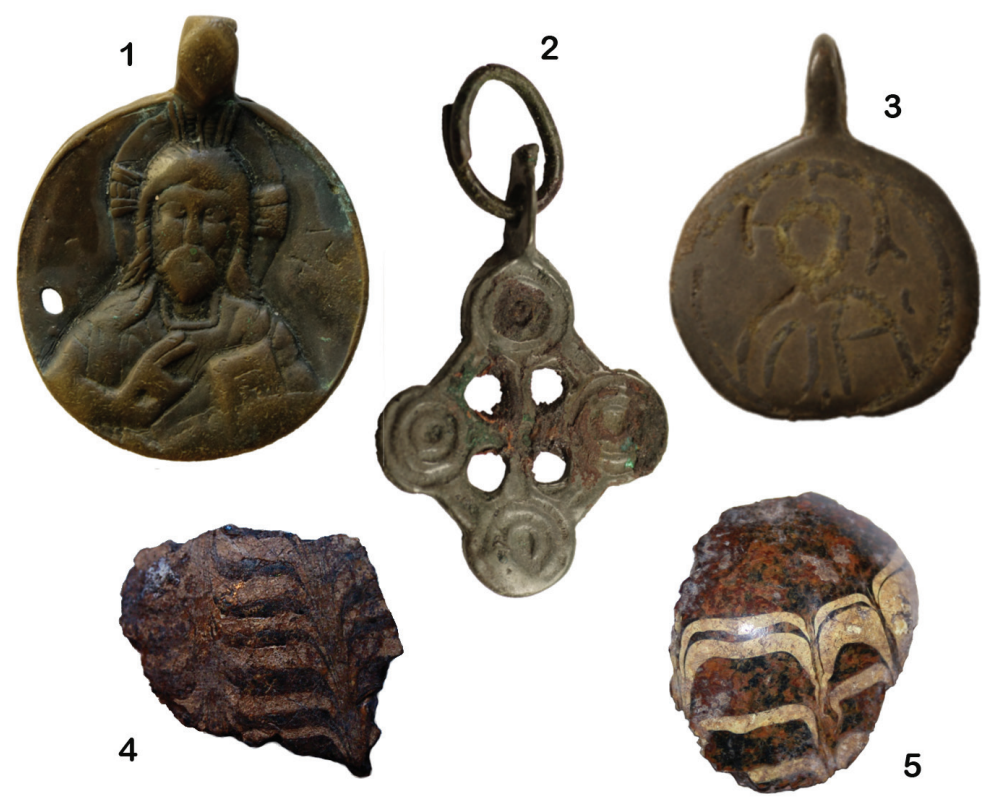

Figure 4. A selection of other Christianity-related artefacts: fragments of ceramic Easter eggs from Tartu, a cross pendant made of an ornamental pin from Viru-Nigula, and pendants depicting Jesus. (1 - AI 3355: 40; 2 -AM A 593: 53; 3 -AI 3357: 267; 4 - TLM A 102: 897; 5 - TLM A 70: 2115). Photos by Tõnno Jonuks and Arvi Haak 2013.

which was found in a wealthy female burial at Kukruse, should probably be interpreted similarly (see below; Jonuks \& Mänd \& Vahur in prep.).

Some alternative sources have been connected to Christianity, such as lunu$l a$-shaped pendants. Baiba Vaska has associated those pendants with Christianity, especially when found as part of a necklace carrying also cross-pendants (Vaska 2003: 99). Lunulae dating from the Late Iron Age and the Middle Ages have been identified with solar and moon symbolism and therefore could be seen as symbols of Virgin Mary (Vaska 2003: 114; Engemann 2004).

Toomas Tamla (1997) has also associated numerous bronze vessels found all over Estonia, but most numerously from the northern part, with the Christian mission. Danish priests are described in the Chronicle of Henry of Livonia (HCL 1982) to send holy water to distant villages where they could not go on their 
own to baptise folk before the Brethren Order. According to Tamla (1997), the bronze vessels, many of which are decorated with Christian symbols, could have been used for carrying holy water and ended up in the hands of local peasants who buried the vessels as hoards.

In addition to symbolic artefacts, there are three main features from the archaeology of burials that have been referred to in the discussion about Christianity - inhumation, orientation and grave goods. As a starting point, usually the dogmatic approach of a Christian burial is chosen. According to this it must be an inhumation burial, orientated to the west, facing to the east, and the grave is supposed to be void of grave goods. It is apparent that most Christian burials from Christian society do look like this, but exceptions to such a dogmatic approach can be found everywhere, including deeply Christian societies. Therefore, a question should be raised about if it is at all justified, while interpreting Christian symbolism, to look for dogmatic Christian customs in officially non-Christian contexts?

According to the Christian tradition, inhumation is preferred. At the same time cremation has always been known in the Christian world and was widely used in Early Christianity (Mitchell 1981: 457). But cremation was practiced in extreme situations also in the Middle and Modern Ages. This was supported by a letter from Pope Innocent III in 1214/1215, which allowed local neophytes in Livonia to choose their burial custom according to their preferences (see Leimus 2011: 11 and references therein). From Estonian sources we know from the Chronicle of Henry of Livonia (HCL 1982: XXI, 4) how the body of Livonian chief Kaupo was cremated after the battle in Estonia. He was lethally wounded, received sacraments and bequeathed everything to the church. After his death he was cremated and his bones were taken back to Livonia. Such descriptions can also be found elsewhere; for example, a Russian soldier cremated on the field after the battle, according to the Livonian Rhymed Chronicle (Vahtre 1960: 73). But even if cremation among the neophytes was officially tolerated by the church, the cases of when it was used can still be considered unique. The most obvious explanation for such instances is that the corpses of Christian warriors, killed far away from their homes, were difficult to transport and so exceptional burials were used. But considering the papal permission and cases known from the chronicles, it means that it is not justified to handle all cremation burials from the Middle Ages as pagan.

In spite of the legal permission for cremation it is clear that inhumation has always dominated in the history of Christianity. On the one hand, inhumation is connected to Christian theology through the resurrection of the soul and the Last Judgment, while during cremation both the body and soul would be destroyed. The preservation of the body became important in order to reconnect 
the soul and body after the Last Judgment, hence cremation was excluded. But, on the other hand, there was also a political reason as cremation was widely used by Iron Age people in northern Europe, against whom missionary wars were started in the 8th century. So cremation became a symbol of paganism and was officially sanctioned by Charles the Great in 789, in the context of a missionary war against the Saxons (Sanmark 2004: 37). From this time onward cremation became a symbol of Paganism, despite the fact that it has always been used in Christian context as well.

Another important feature in the archaeology of burials is the orientation of the body, by which the head should be orientated to the west, facing to the east. According to theology, the body stays in the grave until the Last Judgment Day, when bodies and souls are reunited and they rise to face God coming from the east. Simultaneously another and probably more popular version was spread, according to which the soul of the deceased moved directly to Heaven or Hell. Both concepts separately or their symbiosis was simultaneously in use and caused no contradiction, at least not for common people (Baun 2008: 615).

During Estonian Late Iron Age, literally every single direction was used for orientation (Kurisoo 2011: 27). Still, Kaberla and Pada cemeteries stand out from the generally heterogeneous picture. Both of them include more than one burial using Christian symbolism, but the orientation of Late Iron Age burials was dominantly towards the west (ibid.: Appendix 5). At the same time, the majority of burials orientated to the west contained no other signs referring to Christianity. When considering the orientation as an indication of Christianity, the best example should be Kukruse cemetery (Lõhmus et al. 2011). All major directions for the orientation were represented among fifty inhumations. A specific group of six persons stood out - there were two male and four female burials close together, all orientated to the west and all wealthier than other burials in the studied part of the cemetery. In addition, Christian symbolism was represented only in the four female burials. This grouping is in a certain contradiction with other examples, as was the case in Pada and Kaberla cemeteries, where it was not possible to determine such groups (Kurisoo 2011: 27).

But despite the example from Kukruse, and having the cases of Kaberla and Pada in mind, the orientation alone should not be considered as a primary indicator of a Christian burial. The orientations of Late Iron Age burials are open to different interpretations, in addition to the possible connection to Christian theology, but most of them are not traceable any more. One should keep in mind that the orientations of burials from the Middle and Modern Ages have varied as well, including those of Christian origin. This issue is also well-known elsewhere (see Jonsson 2009: 98f. and references therein) and some studies value more the position of the burial - either in the church or close to it - and not so 
much the orientation of the body (Poulík 1975: 99; Lucy 2000; Pluskowski \& Patrick 2003: 46 and references therein).

The issue of grave-goods is the most widely discussed issue in connection to Christianity besides cross symbolism. Again a dogmatic view is accepted, according to which in the case of a Christian burial the grave is supposed to be void of grave goods. Similarly to cremation, this is also a ban that was imposed in the 8th century in the context of the Saxons' mission. During the crusade the opposition between paganism and Christianity became an essential topic and northern European Iron Age tradition of using grave goods became a pagan symbol. Some scholars suggest that nothing in the Christian doctrine bans the use of objects at a burial (Kiefer-Olsen 1997: 187). This means that the rule not to bury grave goods should be understood similarly to cremation neither of them is proscribed in script or in theology, but during the crusades they became symbols of Paganism due to historical reasons. This suggests that even though they were officially prohibited, grave goods have been found from burials throughout the Middle Ages and Modern Times (Valk 2001) until today. It is generally known and accepted that objects such as swords, bishop regalia, etc., which were used in Christian burials from Early Christianity through to Modern Ages, indicate the deceased's rank (see Kiefer-Olsen 1997; Gräslund 2000: 84ff.; Staecker 2003). The majority of grave goods used in pagan burials (e.g. weapons) are usually also interpreted as symbols of rank. In addition to the aforementioned obvious symbols of position, there is also food placed in Christian burials, for instance, in Denmark during the Middle Ages (Kiefer-Olsen 1993), which makes such burials look pagan. Still, there is a clear theological difference in the meaning of goods placed with burials in pagan and Christian contexts. Grave goods in pagan burials, as it is commonly thought, should guarantee that the soul of the deceased could continue its existence and therefore the food, rank equipment, and seldom also tools, were placed in the grave with the body. In Christian theology, on the contrary, such items were not necessary as the soul of the deceased did not need them while waiting for the Judgement Day in the grave, enjoying Heaven or suffering in Hell.

In addition, the concept of grave goods can also be understood very differently. Some authors have a radical view, regarding all the preserved objects found from the grave as grave goods, including jewellery, metal ornaments for clothes and fastening instruments like brooches. These have been considered as evidence of syncretism and it has been proposed that the medieval church in Estonia had to compromise with old beliefs and let people add grave goods to a Christian burial (Tamla 1993). In fact, ornaments of clothes and other attachments should not be considered as grave goods (Thunmark-Nylén 1995: 162; Gräslund 2000: 84), and the custom to bury the dead in richly ornamented 
festive dresses was followed in Estonia until the end of the 13th century and it was in any way against the Christian doctrine or common customs.

To conclude the discussion on sources, it has to be stated that the source material about Christianity is much more varied than just cross symbols. But as all these symbols and burial custom features occur in different cultures and times with different meanings, the concrete context must be considered. Thus, the wider context in Northern Europe in the 12th and 13th centuries suggests that new symbols and changes in burial customs originate from the Christian religion spreading to the north. But what does it mean? As explained above, there is no reason to look for some universal pagan background and those changes should be interpreted as emanating from Christianity. Traditionally it has been stated that during the Late Iron Age 'Christian influences' were introduced into pagan religion. But what did those influences mean, how did they change religion as a whole and - most speculatively but methodologically interestingly - how to describe the identity of such people who use Christian symbolism while living in a pagan society?

\section{DISCUSSION: PAGANS OR CHRISTIANS?}

There are several different patterns created to study the spread of Christianity to northern Europe (e.g. Birkeli 1973; Lager 2002; Sanmark 2004; Musin 2012). Considering the major cultural centres around Estonia in the Final Iron Age, the 11th-13th centuries, the most important of them are studies about south-Scandinavian and north-west Russian Christianity. However, none of the patterns proposed for these areas seem to apply to the Estonian material. We presume that one of the major reasons for this is the different historical context of how and when Christianity reached Estonia. The spread of Christianity from the 5th century Mediterranean to northern Europe lasted for almost a millennium, during which the original religion met different cultures, societies and religions. Simultaneously, the social context changed as in many parts the shift to Christianity meant centralised power systems, changed trading routes and a new, cross-European identity. All this suggests that Christianity also changed during the process and missionary tactics varied in different cultural and political contexts (e.g. Muldoon 1997; Edwards 2005: 122). In this respect it is important to note that in the early days of Scandinavian and Russian missionary work, the first missionaries had to accept strong and powerful nonChristian societies and thus different kinds of compromises were usual (e.g. primsignatio, simplified Christian teachings, etc.; see more in Sanmark 2004). By the time of the Baltic Crusade the situation was different, Christian com- 
munities were in an increased position of strength and therefore compromises such as primsignatio were not necessary and no longer practiced.

Besides different missionary practices, the methodological aspect needs to be considered - we tend to assume that Christian symbolism indicates Christianity in whatever form it appears. Alex Pluskowski and Philippa Patrick (2003: 30) have stressed that the approach towards Christianity is simplified everywhere and there is a need to re-conceptualise the notion of 'Christianity', even though a good alternative is yet to be found. To us it seems more promising to focus on the general picture, which might not even contain classical references to Christianity, but the general view is nevertheless Christian. According to our material it seems that the situation might have been much more complicated and there could have been 'Christians' who had nothing to do with the 'real' Christianity.

As explained previously, it is very dangerous to build interpretations on a single aspect, such as burial orientation, presence or absence of grave goods or cross symbolism. Moreover, many of these aspects come from dogmatic Christianity or from another time period and have therefore nothing to say about medieval Christianity ${ }^{2}$. It is a well-known problem that Christianity is seen as one unit and the definition of Christianity derives too often from our modern understanding of religion or occasionally from medieval but dogmatic Catholicism (see also Kilbride 2000). But contemporary northern European Lutheranism and medieval Catholicism, especially in the context of crusades, are more or less different religions, whereas in the latter Christ himself does not represent an innocent martyr but a victorious warrior, and to defend the Christian society, pagans were permitted to kill (e.g. HCL 1982: XXIII, 10; Gräslund 2000: 95; Jensen K.V. 2011; cf. also King 2008).

Moreover, most of our literary sources about medieval Christianity are about the official religion, which says little, if anything at all, about the religiosity of common people outside urban culture, especially about the eastern side of the Baltic region before the 13 th century.

Still, the rich use of Christianity-related symbolism points clearly to the position that religion had in the Baltic area in the 12th and 13th centuries, right before the North-East Crusade brought the last 'pagan' stronghold in Europe to an end. One of the most recent finds allowed us to have a closer look at a $40+$ years-old female inhumation from the early 13th century Kukruse cemetery in north-eastern Estonia (Fig. 5). She was not wearing the most classical item, the cross-pendant, and she was accompanied by a number of grave goods but, nevertheless, we can speculate that this was a burial of a Christian female. Her body was covered with a set of numerous breast chains, there were eight and nine circlets around her right and left forearm, respectively, her clothing 
was decorated with different patterns made of small bronze spirals, etc. At the foot of the burial there was a ceramic vessel, once filled with food, and also a rich set of grave goods - a scythe, a knife, etc. On her left shoulder, there was a small bronze horse-shaped pendant, which had most probably been originally attached to the breast chain or clothing. From the religious perspective, the most interesting find was a necklace with seven round silver pendants carrying different signs in between glass beads. The most central and prominent pendant depicted a cross, and on both sides of it, pendants were decorated with lunula-shaped imprints. Often a cross symbol is created by combining four of such motives, but on these pendants no more than three signs could have been placed. The next pair represented pentagrams, which is rather unique in Estonia, and until then only one example of a similar kind had been known - from Ubina hoard, dated to the beginning of the 12th century (Tamla et al. 2006: Fig. 3:2). The set ended with two smaller pendants with a significantly simpler ornament. The set was probably made by one master and possibly also ordered as one unit. Thus, we could assume that the symbols and the pattern in which they were arranged had a specific meaning for the owner as well as the rest of the community.

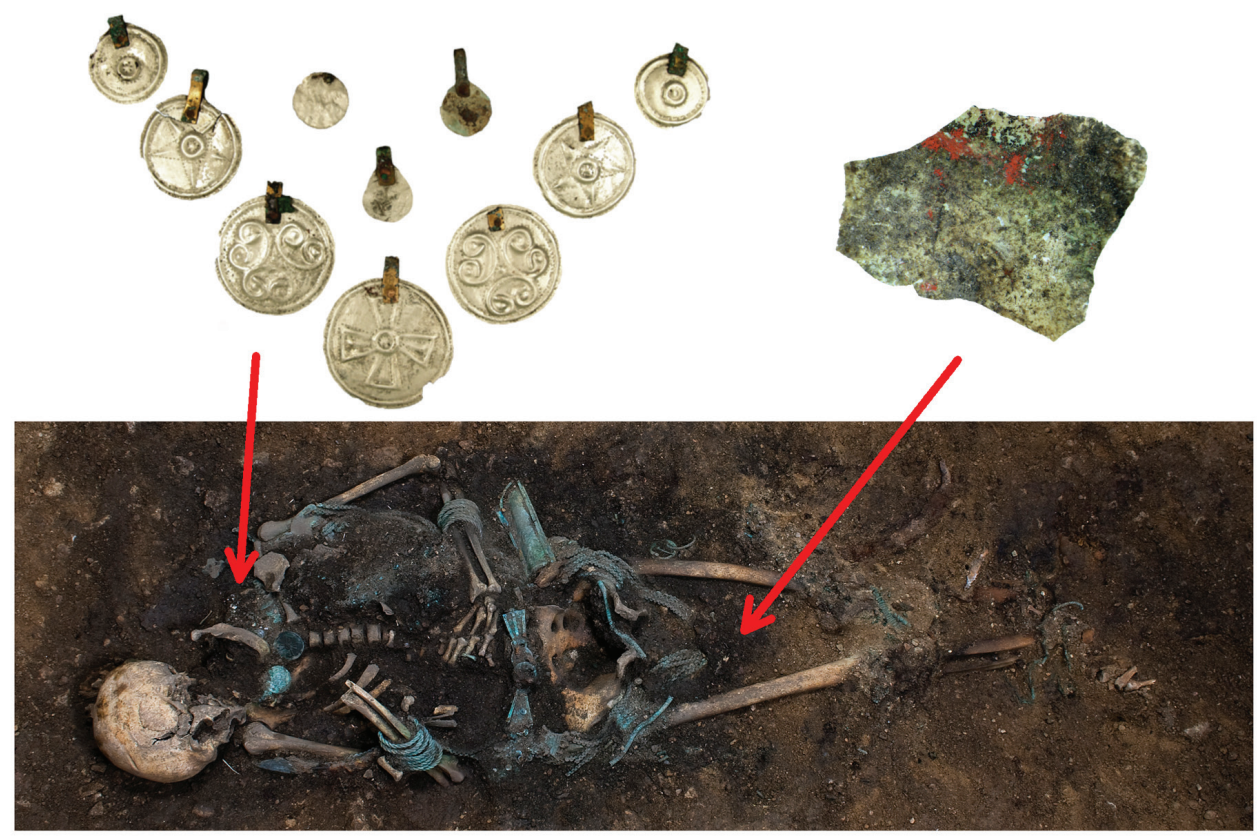

Figure 5. Burial VII from Kukruse early 13th-century cemetery. Close-ups of red ochrepainted egg and necklace. Note the symmetrical position of pendants in the necklace. Photos by Marko Usler, Signe Vahur and Tõnno Jonuks 2010. 
In addition, an egg was found in between her thighs, on top of the clothing and ornaments, and thus on display to all mourners. Small preserved fragments of red colour were discovered on the eggshell. This find is the first of its kind in Estonia, while many are known from the lower reaches of the River Daugava in Latvia, from the 12th and 13th centuries. It can be speculated that in some cases an egg buried with the deceased was there simply as food (Stenberger 1977: 472; Urtāns 1973), but considering the coloured shell and displayed position it is likely that this has more to do with the symbolic meaning. We could consider both interpretations here - the pagan and Christian symbolism. According to the former, the egg could be connected with the creation myth, according to which the world originates from an egg, and birds have also been associated with soul-birds (Nazarova 2006: 152). According to the latter, the colourful egg in the grave could be connected with the Easter egg tradition, symbolising the resurrection of the soul. The spread of eggshells in graves is eye-catching: in the eastern Baltic region these cases appear predominantly in the wealthy graves in coastal areas, and are limited to the 12th and 13th centuries, which points to some external influences rather than a local pagan mythical tradition. Considering the fact that eggs were coloured and found from graves, the latter interpretation - the egg as a symbol of the soul's resurrection - seems more plausible. But it does not necessarily mean that it was placed there just as a symbol of Christianity. The egg could just as well have transformed into a symbol of the soul's resurrection in pagan societies (Shepard 2008: 145), but even then it would probably have preserved something from its original meaning.

In the Kukruse case we are seemingly dealing with a wealthy female burial, and deciding by her grave goods and the food in the grave, her soul most likely had to continue a way of life similar to that before her death. At the same time Christian symbols were clearly demonstrated in her as well as the three neighbouring female burials (see above). It is interesting that among fifty studied burials this group of six burials was clearly distinctive - they were all buried close by (four females, two males), one male and all females were richly equipped for the Afterworld and all four females had either round silver pendants with cross-signs or a cross pendant on them. The latter, the biggest of its kind found in Estonia, was probably of local origin. While cross symbolism is present in the case of those four, it is interesting to note that the rest of the burials of the explored part of the cemetery did not include anything to symbolise their religion - neither Christian nor pagan.

The combination of crosses and rich grave goods can also be traced in other cemeteries, although not conclusively. So far only the appearance of cross pendants has been studied (Kurisoo 2012), according to which it could be concluded that it was mainly females and children that wore cross pendants, and they 
were very rarely found in male burials. Also, burials with cross pendants do not differ by any other features from the rest of the burials in the community - but for this, the burial ritual seems to have been similar. So the main conclusion so far is that in the late 12 th and 13th centuries some of the deceased were marked with Christian symbolism, but buried in the same way as the rest of the members of the community. This apparent mixing of religious phenomena shows that people of that time, who used Christian-related symbolism, did not differentiate themselves from the rest of the community. It is possible that the rich, locally produced and used Christian symbols had a meaning in society at the time, so it seems plausible to suggest that a kind of local interpretation of Christianity was represented in the religion of the 12 th and 13 th-century Estonia. So, what was the reason and what was their religion?

\section{Who is a Christian? What about a Pagan?}

It seems that even though 'Christian influences' proposed traditionally as an interpretation of such Christian symbolism is a relevant term, the term itself is very diffuse with complicated meanings, and needs to be reconsidered (Pluskowski \& Patrick 2003). Too often archaeologists and historians of religion seem to identify the early Christian as someone who has changed the religious identity together with all necessary sacraments, who excludes the pagan gods and follows Christian doctrines (cf. also Musin 2012). In other words - a Christian in these early medieval societies could have been a person who corresponded to the doctrinal definition of the religion. Without any doubt such a narrow definition does not apply to transition societies and the features of one's religious identity were more diffused. It is even more obvious when studying the use of terms 'Christian' and 'Pagan' in Medieval Chronicles. It is widely known that the term 'Pagan' was not merely used when talking about religious opponents but in many cases about political opponents as well, irrespective of their religious background (Mägi 2002: 152; Tamm \& Jonuks forthcoming). The medieval rural population in Estonia has constantly been called 'neophytes' in chronicles, even though the land and the folk had officially been Christianised for centuries (Kala 2006). Such a use of the term in Medieval Chronicles appears most clearly in the context of heresy, even though heretics considered themselves to be Christians (e.g. Janson 2003). And this is where we reach the issue of religious identity that we have traditionally based on seemingly objective and opposing official definitions - 'Christian' and 'Pagan'. Yet, especially in transitional societies the situation was much more merged and therefore it happened too often that people who considered themselves Christians were 
labelled as Pagans. In this context it has not been discussed what could have been the religious identity of the people that used Christian symbolism but lived in a pagan society.

As in those days Christian symbolism spread among part of the Estonian population, we should focus on both personal and group identities. Identity has been thoroughly explored in archaeology and therefore multiple different definitions are in use. Margarita Díaz-Andreu and Samantha Lucy have defined identity as "inextricably linked to the sense of belonging. Through identity we perceive ourselves, and others see us, as belonging to certain groups and not others" (Díaz-Andreu \& Lucy 2005: 1). Although we agree to the aspect of belonging, the distinction between 'us' and 'others' seems to be too clear-cut in the definition. In light of the archaeological finds from the Estonian Final Iron Age and their context, Timothy Insoll's study (2007) about religious identities in the Arabian Gulf region seems much more relevant. According to him, religious identities may be overlapping and vary much depending on the observer's position. We understand the religious identity as both personal and collective self-identification, and as something that is marked by using religious symbolism. The crucial aspect of this definition is the way the person in the past understood him/herself and what could have been the word to describe him/ her. This means that the official definitions of 'Pagan' and 'Christian' based on doctrinal categories are of no more importance than the more speculative and subjective assumptions of what those people thought about themselves (cf. also Makarov 2009: 114).

Considering the rich local variety in using the cross and other Christian symbols at the time when all the major cultural centres around Estonia were experiencing a shift in religion, it seems plausible that the Estonian nobility (or at least a part of it) identified themselves as 'Christians'. In this context it must be kept in mind that characteristically of the 12th-13th-century religious worldview 'Christianity' and 'Paganism' did not eliminate one another. It is apparent in many medieval chronicles that pagan gods and supernatural beings existed in the Christian world as well and represented evilness (Jensen C.S. 2011). What mattered was who was more powerful (Kala 2006: 3). We may assume that such an approach was also represented in the Late Iron Age Estonian religion and Christ as a god could have been regarded merely as one of the many in the gods' family, and in the 12th and 13th centuries more powerful than others. ${ }^{3}$ Thus, from a very basic standpoint we can assume that from the 11th century onwards the local population, and especially the nobility, was aware of Christianity as a new religion and its adoption did not result in a religious shift and exclusion of the existing or former gods. The wearing of crosses and other Christian symbolism in plain view indicates that it was 
important for them to express their religious identity despite whatever the official or theological understanding of a 'Christian' was. It is also well known that Christian symbolism most often occurs in pre-Christian contexts, in which people possibly had to express their identity (Golubeva 1997; Staecker 2003; Jonuks 2009: 298; Madgearu 2012: 310). With all this in mind, the local nobility could have had closer relations with foreign and 'proper' Christian nobility. Medieval Christianity was mostly based on collective identity (Sanmark 2004: 182), which probably gave some ground for the locals to identify themselves as part of the wider nobility as well.

But what could have it meant to be a Christian in the 12th-13th-century Estonia? What could have been the themes in medieval Christianity that were attractive to pagan societies and could therefore have been the first to be integrated into the pagan religion?

\section{Themes}

In spite of wearing Christian symbolism and possibly considering themselves Christians, the religious knowledge of local folk differed considerably from the doctrinal treatment. If we presume that one of the major attractions of the new religion was its prestigious image, it is most likely that some elements of the Christian teaching were taken over as well. When studying the latter, we must remember that this sort of knowledge spread in a liminal situation from one newly Christianised society to another, or even in military contexts. And this definitely designated the topics that were significant and shaped the form of Christianity. It is most likely that we can leave aside complicated and doctrinal concepts, like the sin, the Holy Trinity, etc. (Sanmark 2004: 184). As Alexandra Sanmark has suggested, the Christian teaching in transition societies could have been made simpler in order for it to be more compatible with the former religion and in some cases it could have ended up even with what was heresy for the official theology (ibid.: 100).

The first of the attractive themes was probably eschatology together with the concept of the soul's resurrection and the Afterworld. These were some of the central motives in medieval Christianity and without a doubt existed in the Iron Age religion as well. The presence of 'proper' grave goods - i.e., objects placed into graves other than ornaments or articles of clothing - can be regarded as a proof of this. From the Migration Period onwards, the number of grave goods increased, comprising mostly weapons, and sometimes also tools or pet animals. According to the present view, these were the items that either belonged to the deceased or symbolised them, and the reason for placing those in the grave or 
on the pyre was that the deceased's soul needed them in the Afterworld. Since the richly furnished inhumation graves started to appear in the 11th century, they also included ceramic vessels. Some of them contained charcoal (Jaanits et al. 1982: 347), but the majority seems to have been once filled with food. The presence of food in graves seems to be the best argument to suggest the existence of the Afterworld as a place where souls of the deceased continue a similar way of life and where they also need tools, weapons and food.

In medieval Christianity the souls of the deceased left the body and entered the purgatory for purification. The purgatory could be multiform, depending on cultural and historical backgrounds, but had a common element of souls being punished or awarded according to the life that they had led. During the Last Judgment souls and bodies were reunited to enjoy the eternal life in Paradise. Along with the official theological treatment, a more popular interpretation was simultaneously in use, according to which souls received an award also prior to the Last Judgment (Baun 2008). If a person led his/her life according to Christian teachings, the soul could have been provided with better conditions, or was punished in the opposite case, already before the Eternality (ibid.: 615). Those two views on afterlife were mixed in medieval religion and even though we could find a contradiction in the theological point of view, they were not in conflict in folk religion (Bernstein 2009: 204).

While the concepts of sin and purification most likely remained unfamiliar to locals, the idea of eternal afterlife in ideal Paradise was probably something that befitted the existing concepts and added some new valuable nuances. It is interesting to note that in many cases the burials with Christian symbolism included a most numerous set of grave goods. A good example of this was seen in Kukruse cemetery, where female burials with Christian symbolism were also accompanied by a rich set of tools and meal pots. This is partly connected with the nobility as they could afford investing in grave goods. At the same time such a connection is striking, emphasising again that there was no semantic contradiction between Christianity and Paganism in these societies.

God was probably another attractive topic besides the Afterworld. The concept of the Holy Trinity has often been considered too complicated for the local people to understand, but it was central in medieval Catholicism. As already mentioned, during the Middle Ages concessions were made in teaching Christianity. Therefore the Holy Trinity was probably not viewed as Trinity but as three different gods. And it is likely that this was acceptable and understandable in Iron Age societies and could have been introduced into their religion and pantheon. In addition to the three supreme gods, a legion of saints was also introduced by Christianity. When looking at medieval folk religion in Western Europe as a close analogy with rich sources available, there are no serious dif- 
ferences between Iron Age pagan and medieval Christian folk religions, and Christian saints were venerated in the same way as gods formerly.

The changed concept of Christ needs to be borne in mind when talking about gods. While the first Christian influences reached Estonia in the 11th and 12th centuries, the Christian world had entered the age of crusades. The concept of god had also adjusted to it and Christ from the crusade period was not a suffering martyr but a victorious warrior. Such a concept was understandable and attractive to both newly baptised and non-Christian societies. And that was most likely the reason why Christian symbols can be found in Estonian Late Iron Age burials, and especially among wealthier ones. But Christianity was characteristic of nobility not only in pagan countries but all over Northern Europe. The first known Estonian Christian originated from the nobility - it was a local chief, called Thabelinus from Virumaa, who was baptised in Gotland, possibly by the priests of the bishopric of Riga (Vahtre 1997: 14). Nicholas and Johannes, two boys from Estonia who were on a pilgrimage to the cathedral of Nidaros (currently Trondheim, Norway) (see Blomkvist 2009), could also be regarded as members of nobility. Otherwise it would have been rather difficult to accomplish the pilgrimage from Estonia to Norway in the memory of their father. There are also some examples that suggest the initiative role of the local nobility in church-building (Johansen 1933: 209; Mäll 1998).

Bearing all this in mind, we can suggest that several individuals from the nobility may have added Christ into their personal pantheon, that the new approach to the Afterworld was probably attractive and, judging by the Christian symbolism on display, they apparently regarded themselves as Christians.

\section{But was it Christianity?}

Although in the 12th and early 13th-century Estonia there were people whose identity could be regarded as Christian and who most probably managed to create their own version of Christianity, they were not Christians for the rest of the Christian world. A crucial issue in speculations about Christianity prior to Christianity is that there have been many versions of the religion. Leaving aside extreme examples, such as eremites, the medieval Christianity was communal (Sanmark 2004: 182) - people belonged to congregations and bishoprics, they visited churches and received regular sacraments, etc. None of these phenomena were possible in Estonia when the church administrative system was absent, there were probably no priests, etc. Despite the fact that Bishop Fulco had been appointed Bishop of Estonia already in 1165, he probably never reached his bishopric. From as early as a century before, there is a message from Adam 
of Bremen (Adam 2002: 16) who says that there was a church being built in Kurland. Such a claim could have partly been propaganda to demonstrate the spread of Christianity, but at the same time it is very likely that the German merchants, who regularly visited the eastern coast of the Baltic, had erected a sacral building for themselves (see also Kala 1998: 44; Rebane 2001: 39; Mägi 2002: 156). As merchants of the period stayed in the same place for a longer time (e.g. for winter), they were probably accompanied by a priest and it would only have been natural to also have a small church or a chapel for services. Nevertheless, those occasional events probably exerted merely negligible influence on the locals. It is more likely that instead of systematic teaching only random elements were obtained from Christianity and reinterpreted in the existing system. Therefore the local Christians could not have been considered 'proper' Christians by the rest of the Western world. Despite the possible Christian identity of the locals they were still considered Pagans and therefore the crusade at the beginning of the 13 th century was non-contradictory.

\section{CONCLUSION}

As any other religion, Christianity has changed in the course of time and also through different contexts. This rather obvious statement seems to have often been neglected when discussing the most complicated phase of Christianity - the transforming society. Far too often claims and concepts of dogmatic Christianity have been ascribed to the mission of northern Europe during those 500 years. During this half a millennium religion changed considerably and as the mission always depended on the local context, there could not have been two similar examples of missions. So, the Christianity that reached the eastern side of the Baltic region during the 11 th and 12 th centuries was also unique. Christianity in the north was still marginal at the time of the Saxons' or even Scandinavians' missions in the 10th and 11th centuries and thus, mission tactics had to consider this. Indeed, the situation was different thereafter and by the 12 th century, when the first Christians appeared in Estonia, religion was in power position. This also changed the mission strategy as reflected in such black-andwhite depictions of local pagans and foreign Christians in medieval Livonia.

Along with the Christianisation of the most important centres of the Baltic region - south of Scandinavia and north-west of Russia - at the end of the 10th century the first cross-shaped pendants appeared in Estonia. It is characteristic that in the beginning, during the 11 th and early 12 th centuries, crosses appeared mostly in hoards, but from the end of the 12th century and especially at the beginning of the 13 th century Christian symbolism was widely used, locally 
interpreted and - most importantly - had a meaning in local religion. Considering the temporal circumstances, we can safely argue that the primary meaning of symbolism came from Christian religion, but the actual use and meaning in each single case could vary. The cross could have also been worn as a protective amulet (but the supernatural power of the symbol derived from Christianity) or as a prestigious symbol of nobility (with the origin of the tradition rooted in foreign Christian nobility), etc. But most likely Christian symbolism was used to mark either a Christian person or somebody who had accepted Christ as one of the gods. Yet, it must be stressed that this self-appearing form of Christianity was not acceptable for the rest of the Christian world. Instead of different forms of Christianity, the crusade at the beginning of the 13th century brought just the 'one and only' version of it to Estonia. So, at the beginning of the 13th century, when the Saxons and Danish started an organised crusade to Estonia, they most likely fought with the nobility, considering themselves, at least partly, Christian. But the crusaders did not regard themselves as Christians as they did not belong into the Christian world but simply practiced their own version of the religion. Therefore it was justified for Christians to call locals pagans, despite whatever the locals' identity and their symbols were. And so, in the end, a crucial question remains: While discussing the religiosity of those years, what should we consider more important: our seemingly objective (and always problematic) characteristics that we apply to an ancient religion on the basis of our sources, or our speculations of what those people thought about themselves?

Research for this article was supported by research project SF 0030181s08 and grant ETF 8956.

\section{NOTES}

1 There are some cross-shaped pendants from the Roman Iron Age, but those clearly represent a special sub-group of the cross, which is determined by the era (3rd-5th century $\mathrm{AD}$ ) but also by the form, and are therefore not comparable or connected to the tradition of using the cross in the Late Iron Age (Jonuks 2009: 228).

2 This is not a methodological problem of Christianity alone but can also be traced among other religions. See Insoll 2007 and references therein for a similar problem of Muslim identities based on different standpoints.

3 It should be mentioned that we purposely avoid using the term 'syncretism'. As William G. Kilbride has pointed out, the usage of this term is based on a false assumption that it is possible to clearly define early medieval Christianity or, moreover, paganism, which means that the concept of syncretism is founded upon a false antithesis and should therefore be rejected (Kilbride 2000: 8). 


\section{ABBREVIATIONS}

AI - Archaeology collection at the Institute of History, Tallinn University

TLM - Archaeology collection at the Tartu City Museum

AM - Archaeology collection at the Estonian History Museum, Tallinn

\section{REFERENCES}

Adam 2002 = Adam of Bremen. History of the Archbishops of Hamburg-Bremen. Translated with an introduction and notes by F.J. Tschan \& T. Reuter. New York: Columbia University Press.

Baun, Jane 2008. Last Things. In: T.F.X. Noble \& J.M.H. Smith (eds.) The Cambridge History of Christianity, Vol. 3. Early Medieval Christianities, c. 600-c. 1100. Cambridge: Cambridge University Press, pp. 606-624, http://dx.doi.org/10.1017/ CHOL9780521817752.031.

Bernstein, Alan E. 2009. Heaven, Hell and Purgatory: 1100-1500. In: M. Rubin \& W. Simons (eds.) The Cambridge History of Christianity, Vol. 4. Christianity in Western Europe c. 1100-c. 1500. Cambridge: Cambridge University Press, pp. 200-216, http://dx.doi.org/10.1017/CHOL9780521811064.016.

Birkeli, Fridtjov 1973. Norske steinkors I tidlige meddelalder. Et bidrag til belysning av overgangen fra norrøn religion till kristendom. [Nordic Stone Cross in the Early Middle Ages. A Contribution to the Illumination of Transition from Nordic Religion to Christianity.] Skrifter utgitt av det Norske Videnskaps-Akademi I Oslo: Historisk-Filosofisk Klasse, N.S., 10. Oslo: Oslo Universitetsforlaget.

Blomkvist, Nils 2009. Early Agents of Europeanization: Nicholas and Fulco on the Bumpy Road to Twelfth-Century Estonia. In: P. Raudkivi \& M. Seppel (eds.) Sõnasse pü̈̈tud minevik. In honorem Enn Tarvel. Tallinn: Argo, pp. 29-58.

Díaz-Andreu, Margarita \& Lucy, Sam 2005. Introduction. In: M. Díaz-Andreu \& S. Lucy \& S. Babič \& D.N. Edwards (eds.) The Archaeology of Identity. Approaches to Gender, Age, Status, Ethnicity and Religion. London \& New York: Routledge, pp. 1-12.

Edwards, David 2005. The Archaeology of Religion. In: M. Díaz-Andreu \& S. Lucy \& S. Babič \& D.N. Edwards (eds.) The Archaeology of Identity. Approaches to Gender, Age, Status, Ethnicity and Religion. London \& New York: Routledge, pp. 110-128.

Engemann, Josef 2004. Spätantike Funde and Rhein und Mosel. Heidnisch - synkretisch - christlich. In: S. Ristow (ed.) Neue Forschungen zu den Anfängen des Christentums im Rheinland. Jahrbuch für Antike und Christentum. Ergänzungsband. Kleine Reihe 2. Münster Westfalen: Aschendorff Verlag, pp. 17-50.

Golubeva 1997 = Golubeva, Leonilla. Amulety. [Amulets.] Arkheologiia. Drevniaia Rus'. Byt i kul'tura. Moskva: Nauka, pp. 153-165.

Gräslund, Anne-Sofie 2000. The Conversion of Scandinavia: A Sudden Event or a Gradual Process? In: A. Pluskowski (ed.) Early Medieval Religion. Archaeological Review from Cambridge, Vol. 17, No. 2, pp. 83-98.

HCL 1982 = Henriku Liivimaa kroonika = Heinrici Chronicon Livoniae. Transl. by R. Kleis. Tallinn: Eesti Raamat. 
Hupel, August Wilhelm 1774. Topographische Nachrichten von Lief- und Ehstland. Bund I. Gesammelt und herausgegeben durch August Wilhelm Hupel. Riga: Johann Friedrich Hartknoch. Available at http://dspace.utlib.ee/dspace/ handle/10062/1850, last accessed on November 27, 2013.

Insoll, Timothy 2007. Changing Identities in the Arabian Gulf. Archaeology, Religion, and Ethnicity in Context. In: T. Insoll (ed.) The Archaeology of Identities. A Reader. London \& New York: Routledge, pp. 308-325.

Jaanits, Lembit \& Laul, Silvia \& Lõugas, Vello \& Tõnisson, Evald 1982. Eesti esiajalugu. [Estonian Prehistory.] Tallinn: Eesti Raamat.

Janson, Henrik 2003. What Made the Pagans Pagans? In: R. Simek \& J. Meurer (eds.) Scandinavia and Christian Europe in the Middle Ages. Bonn: Hausdruckerei der Universität Bonn, pp. 250-256.

Jensen, Carsten Selch 2011. 'Verbis non verberibus': The Representation of Sermons in the Chronicle of Henry of Livonia. In: M. Tamm \& L. Kaljundi \& C.S. Jensen (eds.) Crusading and Chronicle Writing on the Medieval Baltic Frontier. Surrey \& Burlington: Ashgate, pp. 179-206.

Jensen, Kurt Villads 2011. Bigger and Better: Arms Race and Change in War Technology in the Baltic in the Early Thirteenth Century. In: M. Tamm \& L. Kaljundi \& C.S. Jensen (eds.) Crusading and Chronicle Writing on the Medieval Baltic Frontier. Surrey \& Burlington: Ashgate, pp. 245-264.

Johansen, Paul 1933. Die Estlandliste des Liber Census Daniae. Kopenhagen: H. Hagerup \& Reval: F. Wassermann.

Jonsson, Kristina 2009. Practices for the Living and the Dead: Medieval and PostReformation Burials in Scandinavia. Stockholm Studies in Archaeology, Vol. 50.

Jonuks, Tõnno 2009. Eesti muinasusund. [Prehistoric Religions in Estonia.] Dissertationes archaeologia Universitatis Tartuensis 2. Tartu: Tartu University Press. Available at http://dspace.utlib.ee/dspace/bitstream/handle/10062/9494/ Jonukst\%C3\%B5nno.pdf?sequence=1, last accessed on November 27, 2013.

Jonuks, Tõnno 2012. Rahvuslus ja muinasusund: religioon eestluse loojana. [Nationality and Prehistoric Religion: The Making of Estonian Identity.] Ajalooline ajakiri, No. 3/4, pp. 269-285. Available at http://ojs.utlib.ee/index.php/EAA/article/ view/769/748, last accessed on October 2, 2013.

Jonuks, Tõnno \& Mänd, Raivo \& Vahur, Signe in prep. Eggshells as Grave Goods from Late Iron Age Burials: Possible Interpretations on the Example of the Late 12th - early 13th Century Kukruse Cemetery.

Kala, Tiina 1998. Vana-Liivimaa ja ristiusustamine. In: S. Rutiku \& R. Staats (eds.) Eestimaa, Liivimaa ja Lääne kristlus: Eesti-Saksa uurimusi Baltimaade kirikuloost = Estland, Lettland und westliches Christentum: Estnisch-deutsche Beiträge zur baltischen Kirchengeschichte. Kiel: Friedrich Wittig Verlag, pp. 39-74.

Kala, Tiina 2006. Ristimine paganate ja kristlaste pilgu läbi. [Baptism as Seen by Pagans and Christians.] Tuna, Vol. 3, pp. 8-26.

Kaljundi, Linda 2008. Waiting for the Barbarians: Reconstruction of Otherness in the Saxon Missionary and Crusading Chronicles, 11th-13th Centuries. In: Erik Kooper (ed.) The Medieval Chronicle, Vol. 5. Amsterdam \& New York: Rodopi, pp. 113-127. 
Kallis, Irita 2010. Kaberla kalmistu 12.-13. sajandi klaashelmed. [Glass Beads from Kaberla Cemetery in the 12th-13th Centuries.] In: Ü. Tamla (ed.) Ilusad asjad. Tähelepanuväärseid leide Eesti arheoloogiakogudest. Muinasaja teadus, Vol. 21, pp. 149-170.

Kieffer-Olsen, Jakob 1993. Grav og gravskik $i$ det middelalderlige Danmark. [Burial and Burial Customs in Middle Ages Denmark.] Højberg: Afd. for middelalderarkæologi.

Kieffer-Olsen, Jakob 1997. Christianity and Christian Burial. The Religious Background, and the Transition from Paganism to Christianity, from the Perspective of a Churchyard Archaeologist. In: C.K. Jensen \& K.H. Nielsen (eds.) Burial \& Society. The Chronological and Social Analysis of Archaeological Burial Data. Aarhus \& Oakville, Conn.: Aarhus University Press, pp. 185-189.

Kilbride, William K. 2000. Why I Feel Cheated by the Term 'Christianisation'. In: A. Pluskowski (ed.) Early Medieval Religion. Archaeological Review from Cambridge, Vol. 17, No. 2, pp. 1-17.

King, Karen L. 2008. Which Early Christianity? In: S.A. Harvey \& D.G. Hunter (ed.) The Oxford Handbook of Early Christian Studies. Oxford: Oxford University Press, pp. 66-84, http://dx.doi.org/10.1093/oxfordhb/9780199271566.003.0004.

Kurisoo, Tuuli 2011. Ristripatsid Eesti 12.-13. sajandi laibakalmistutes: ehted, kristlaste või paganate tunnused? [Cross-Shaped Pendants in the 12th-13th-Century Inhumation Burials: Adornments or Signs of Christians or Pagans?] Bachelor thesis. Manuscript at the University of Tartu Library. Available at http://www. arheo.ut.ee/docs/BA11_Kurisoo.pdf, last accessed on October 3, 2013.

Kurisoo, Tuuli 2012. Ristripatsid Eesti 12.-13. sajandi laibakalmistutes: kas ehted või usu tunnused? [Cross-Shaped Pendants in the 12th-13th-Century Inhumation Burials: Adornments or Signs of Belief?] Õpetatud Eesti Seltsi aastaraamat, pp. 213-234. Available at http://www.ut.ee/OES/wp-content/uploads/Kurisoo.pdf, last accessed on October 3, 2013.

Lager, Linn 2002. Den Synliga Tron. Runstenskors som en spegling av kristnandet $i$ Sverige. [The Visible Faith: Runestone Crosses as Reflections of the Christianisation of Sweden.] Uppsala: Institutionen för arkeologi och antik historia, Uppsala universitet.

Laul, Silvia \& Valk, Heiki 2007. Siksälä: A Community at the Frontiers. Iron Age and Medieval. CCC Papers 10. Tallinn \& Tartu: University of Tartu.

Leimus, Ivar 2009. Läänemere kristlikud paganad. [The Christian Pagans of the Baltic Sea.] Tuna, Vol. 4, pp. 5-22. Available at http://rahvusarhiiv.ra.ee/public/TUNA/ Artiklid_Biblio/LeimusIvar_Laanemere_kristlikud_TUNA2009_4.pdf, last accessed on November 27, 2013.

Leimus, Ivar 2011. Iura christianorum - Läti Henriku sõnakõlks või nõks paganate alistamiseks? [Iura Christianorum: A Catch Phrase by Henry of Livonia or a Trick to Subdue Pagans?] Tuna, Vol. 1, pp. 9-19. Available at http://rahvusarhiiv.ra.ee/ public/TUNA/Artiklid_Biblio/LeimusIvar_Lura_Christianorum_TUNA2011_1. pdf, last accessed on October 11, 2013.

Lõhmus, Mari \& Jonuks, Tõnno \& Malve, Martin 2011. Archaeological Salvage Excavations at Kukruse: A Modern Age Road, 13th-15th Century Cemetery. In: E. Oras \& E. Russow (eds.) Archaeological Fieldwork in Estonia 2010. Tallinn: Muinsuskaitseamet, pp. 103-114. 
Loorits, Oskar 1962. Zur christlichen Terminologie bei den Esten, Liven und Letten. Eesti Vaimulik Raamat. Uppsala: Arostryck.

Lucy, Samantha 2000. The Anglo-Saxon Way of Death. Stroud: Sutton Publishing.

Madgearu, Alexandru 2012. The Significance of the Early Christian Artefacts in PostRoman Dacia. In: Orsolya Heinrich-Tamáska \& Niklot Krohn \& Sebastian Ristow (eds.) Christianisierung Europas. Entstehung, Entwicklung und Konsolidierung im archäologischen Befund. Regensburg: Schnell \& Steiner, pp. 299-317.

Mägi, Marika 2002. At the Crossroads of Space and Time: Graves, Changing Society and Ideology on Saaremaa (Ösel), 9th-13th Centuries AD. CCC Papers 6. Tartu: University of Tartu.

Mägi, Marika 2004. From Paganism to Christianity: Political Changes and Their Reflection in the Burial Customs of 12th-13th Century Saaremaa. In: D. Kattinger \& J. Olesen \& H. Wernicke (eds.) Der Ostseeraum und Kontinentaleuropa 1100-1600. Einflußnahme - Rezeption - Wandel. CCC Papers 8. Schwerin: Thomas Helms Verlag, pp. 27-34.

Makarov 2009 = Makarov N. Iazychestvo i khristianstvo. [Paganism and Christianity.] In: Arkheologiia Severnorusskoi derevni X-XIII vekov. Srednevekovye poseleniia i mogil'niki na Kubenskom ozere. Tom III. Moskva: Nauka, pp. 106-115.

Mäll, Jaak 1998. Verwaltungsgeschichte und Christianisierung der Insel Oesel im 13.-14. Jahrhundert. In: N. Blomkvist (ed.) Culture Clash or Compromise? The Europeanisation of the Baltic Sea Area 1100-1400 AD. Acta Visbyensia XI. Visby: Gotland Centre for Baltic Studies, pp. 158-166.

Merkel, Garlieb Helwig 1798. Die Vorzeit Lieflands: ein Denkmal des Pfaffen- und Rittergeistes. Erster Band. Berlin: Voss. Available at http://dspace.utlib.ee/dspace/ handle/10062/2908, last accessed on November 27, 2013.

Mitchell, Edwin Knox 1981. Death and Disposal of the Dead (Early Christian). In: J. Hastings (ed.) Encyclopædia of Religion and Ethics, Vol. IV. Edinburgh: T\&T. Clark, pp. 456-458.

Moora, Harri 1927. Die Kultur der Esten zur Zeit ihrer Selbständigkeit im Altertum (Eestlaste kultuur muistsel iseseisvus-ajal). Tartu: Veröffentlichung des Archäologischen Kabinetts der Universität Tartu IV.

Muldoon, James (ed.) 1997. Varieties of Religious Conversion in the Middle Ages. Gainesville, FL.: University Press of Florida.

Musin, Alexander 2012. The Christianisation of Eastern Europe in the Archaeological Perspective. In: Orsolya Heinrich-Tamáska \& Niklot Krohn \& Sebastian Ristow (eds.) Christianisierung Europas. Entstehung, Entwicklung und Konsolidierung im archäologischen Befund. Regensburg: Schnell \& Steiner, pp. 497-520.

Nazarova, Eugenija 2006. Funeral Traditions in the Russian North (13th-19th Centuries). In: T. Fischer \& T. Riis (eds.) Tod und Trauer. Todeswahrnehmung und Trauerriten in Nordeuropa. Kiel: Ludwig Verlag, pp. 147-157.

Ó Floinn, Ragnhall 2012. A Review of Early Christianity in Ireland Based on the Most Current Archaeological Research. In: Orsolya Heinrich-Tamáska \& Niklot Krohn \& Sebastian Ristow (eds.) Christianisierung Europas. Entstehung, Entwicklung und Konsolidierung im archäologischen Befund. Regensburg: Schnell \& Steiner, pp. 11-35.

Pauts, Heikki 1997. Pahaga hoburaudsõled Eestis. [One Type of Penannular Brooches in Estonia.] In: Töid ajaloo alalt I. Tallinn: Eesti Ajaloomuuseum, pp. 79-115. 
Pluskowski, Aleksander \& Patrick, Philippa 2003. 'How do you pray to God?' Fragmentation and Variety in Early Medieval Christianity. In: M. Carver (ed.) The Cross Goes North. Process of Conversion in Northern Europe, AD 300-1300. York: York Medieval Press, pp. 29-57.

Poulík, Josef 1975. Mikulčice: Sídlo a peunost knížat velkomoravských. [Mikulčice: The Seat and Stronghold of Great Moravian Princes.] Praha: Academia.

Purhonen, Paula 1998. Kristinuskon saapumisesta Suomeen: Uskontoarkeologinen tutkimus. [On the Arrival of Christianity in Finland. A Study in the Archaeology of Religion.] Suomen Muinaismuistoyhdistyksen aikakauskirja, 106. Helsinki: Suomen Muinaismuistoyhdistys.

Rebane, Peep Peeter 2001. From Fulco to Theoderic. The Changing Face of the Livonian Mission. In: A. Andresen (comp.) Muinasaja loojangust omariikluse läveni. Pühendusteos Sulev Vahtre 75. sünnipäevaks. Tartu: Kleio, pp. 37-68.

Samdal, Magne 2000. Amuletter: Gjenstander med amulettkarakter I vestnorske graver i tidsrommet 350-1000 e.Kr. [Amulets: Objects with Characteristics of Amulets from West-Norwegian Graves from AD 350-1000.] Hovedfagsoppgave I arkeologi med vekt på Norden. Bergen: Unversitetet i Bergen.

Sanmark, Alexandra 2004. Power and Conversion: A Comparative Study of Christianization in Scandinavia. Doctoral thesis. Uppsala: Department of Archaeology and Ancient History, Uppsala University.

Schülke, Almut 1999. On Christianization and Gravefinds. European Journal of Archaeology, Vol. 2, No. 1, pp. 77-106, doi:10.1177/146195719900200105.

Selart, Anti 2008. I am tunc... The Political Context of the First Part of the Chronicle of Henry of Livonia. In: Erik Kooper (ed.) The Medieval Chronicle, Vol. 5. Amsterdam \& New York: Rodopi, pp. 197-209.

Selirand, Jüri 1961. Muistsed matmiskombed eestlaste usundi ja ristiusu-vastase võitluse kajastajana. [Ancient Burial Customs Reflecting Religion of Estonians and Fight against Christianity.] In: E. Jansen (ed.) Religiooni ja ateismi ajaloost Eestis. Artiklite kogumik II. Tallinn: Eesti Riiklik Kirjastus, pp. 71-93.

Selirand, Jüri 1974. Eestlaste matmiskombed varafeodaalsete suhete tärkamise perioodil (11.-13. sajand). [Burial Customs of Estonians during the Early Period of Feudal Relations (11th-13th Centuries).] Tallinn: Eesti Raamat.

Shepard, Jonathan 2008. Slav Christianities, 800-1100. In: T.F.X. Noble \& J.M.H. Smith \& R.A. Baranowski (eds.) The Cambridge History of Christianity. Volume 3. Early Medieval Christianities, c. 600-c. 1100. Cambridge: Cambridge University Press, pp. 130-155.

Staecker, Jörn 1999. Rex Regum et Dominus Dominorum: Die Wikingerzeitliche Kreuzund Kruzifixanhänger als Ausdruck der Mission in Altdänemark und Schweden. Lund Studies in Medieval Archaeology, Vol. 23. Stockholm: Almqvist \& Wiksell International.

Staecker, Jörn 2003. The Cross Goes North: Christian Symbols and Scandinavian Women. In. M. Carver (ed.) The Cross Goes North. Process of Conversion in Northern Europe, AD 300-1300. York: York Medieval Press, pp. 463-482.

Stenberger, Mårten 1977. Vorgeschichte Schwedens. Berlin: Akademie-Verlag.

Tamla, Ülle \& Kiudsoo, Mauri \& Rohtla, Mari-Liis 2006. Rescue Excavations on the Site of Discovery of the Ubina Silver Hoard. In: Ü. Tamla (ed.) Archaeological Fieldwork in Estonia. Tallinn: Muinsuskaitseamet, pp. 231-244. 
Tamla, Ülle \& Kiudsoo, Mauri 2009. Eesti muistsed aarded. [Ancient Hoards in Estonia.] Tallinn: MTÜ Arheoloogiakeskus.

Tamla, Toomas 1993. Viru-Nigula kirik ja Maarja kabel. [The Church of Viru-Nigula and St. Mary's Chapel.] Stilus, Vol. 4. Tallinn: Eesti Arheoloogiaselts, pp. 18-36.

Tamla, Toomas 1997. Bronzeschalen. Zeugnis der Christianisierung Estlands im 13. Jahrhundert. In: M. Müller-Wille (ed.) Rom und Byzanz im Norden. Mission und Glaubenwechsel im Ostseeraum während des 8.-14. Jahrhunderts. Band II. Akademie der Wissenschaften und der Litteratur. Stuttgart: Franz Steiner Verlag, pp. 9-36.

Tamm, Marek 2009. Communicating Crusade: Livonian Mission and the Cistercian Network in the Thirteenth Century. Ajalooline Ajakiri, No. 3/4, pp. 341-372. Available at https://ojs.utlib.ee/index.php/EAA/article/view/375/368, last accessed on November 27, 2013.

Tamm, Marek 2013. How to Justify a Crusade? Conquest of Livonia and the New Crusade Rhetoric in the Early Thirteenth Century. Journal of Medieval History, Vol. 39, No. 4, pp. 431-455, http://dx.doi.org/10.1080/03044181.2013.833541.

Tamm, Marek \& Jonuks, Tõnno forthcoming. Religious Practices of the Native Population of Livonia in the Medieval Written Sources (11th-15th Centuries). In: M. Kõiva (ed.) Mythologia Uralica: Esthonica. Helsinki: SKS.

Thunmark-Nylén, L. 1995. Churchyard Finds from Gotland (11th-12th Centuries). In: I. Jansson (ed.) Archaeology East and West of the Baltic. Theses and Papers in Archaeology. N. S. A 7. Stockholm: University of Stockholm, pp. 161-193.

Tvauri, Andres 2001. Muinas-Tartu: Uurimus Tartu muinaslinnuse ja asula asustusloost. [Prehistoric Tartu: A Study of the Settlement History of the Tartu Prehistoric Hillfort and Settlement.] Muinasaja Teadus, Vol. 10. Tallinn \& Tartu: Teaduste Akadeemia Kirjastus.

Urtāns, Vladislavs 1973. Aizkraukles arheologiskās ekspedīcijas 1972. gada darba rezultāti. [Results of the Fieldwork of the Archaeology Expedition to Aizkraukle in 1972.] Zinātniskās atskaites sesijas: Materiāli par arheologu, antropologu un etnogrāfu 1972 gada pētījumu rezultātiem. Rīgā: Zinātne, pp. 66-70.

Vahtre, Sulev 1960. Bartholomäus Hoeneke Liivimaa noorem riimkroonika 1315-1348. [The Rhymed Chronicle by Bartholomaus Hoeneke 1315-1348.] Tallinn: Eesti Riiklik Kirjastus.

Vahtre, Sulev 1997. Tabelinus. In: S. Vahtre (ed.) Eesti ajalugu elulugudes. 101 tähtsat eestlast. [Estonian History in Biographies: 101 Important Estonians.] Tallinn: Olion, pp. 14-15.

Valk, Heiki 2001. Rural Cemeteries of Southern Estonia 1225-1800 AD. CCC Papers 3. Visby: Gotland University College Centre for Baltic Studies \& Tartu: University of Tartu, Archaeology Centre.

Valk, Heiki 2003. Christianisation in Estonia: A Process of Dual-Faith and Syncretism. In: M. Carver (ed.) The Cross Goes North. Processes of Conversion in Northern Europe, AD 300-1300. York: The Boydell Press, pp. 571-579.

Vaska, Baiba 2003. Solar and Lunar Symbols in Medieval Archaeological Material from Latvia (13th-17th Centuries). Art, Applied Art and Symbols in Latvian Archaeo$\log y$, Vol. 2, No. 39. Humanities and Social Sciences, Latvia. Riga: University of Latvia, pp. 96-117. 